\title{
Michel Foucault, a Política do Corpo e a Expansão da Anatomia Moderna*
}

JAN C. C. RUPP

\section{Introdução}

A Nova Ciência e as artes tiveram um grande desenvolvimento na Holanda do século XVII. Assim como ocorria na Itália, as cidades holandesas foram centros econômicos e eixos políticos e culturais do país. As cidades da Inglaterra e da França, ao contrário, tinham suas Academias Reais. As cidades holandesas desempenharam um importante papel na criação de universidades e academias, e também dos anfiteatros de anatomia, segundo atestam vários escritores da época como Johan de la Court. ${ }^{1}$ Os anfiteatros foram fundados em mais de doze cidades - entre os mais importantes estiveram os de Leiden (1597), Delft (1614) e Amsterdã (1619). ${ }^{2}$ Tornando-

* Este artigo foi publicado originalmente no Journal of Historical Sociology, vol. 5, $\mathrm{n}^{\circ} 1$, março de 1992. Versões anteriores deste trabalho foram apresentadas no seminário de professores e alunos de pós-graduaçāo do Departamento de Sociologia da Universidade de Essex, em novembro de 1990, e no congresso da Sociedade Holandesa para o Estudo da História da Sociedade, em maio de 1991. Agradeço a Catherine Crawford, Bryan S. Turner e a dois pareceristas anônimos da Physis pelos comentários. [Tradução de Vera Pereira.]

1 J. de la Court, Politike Dircoursen, Amsterdã, 1662, pp. 46-7 e 78.

2 Em 1622, Amsterdã tinha cerca de 105 mil habitantes, Leiden tinha 45 mil e Delft 23 mil. Leiden e Delft situam-se entre Amsterdã e Haia/Roterdã. 
se influentes centros culturais, eles deram grande contribuição à produção, difusão e consumo das artes e ciências. ${ }^{3}$

Homens de erudição organizavam encontros científicos e estimulavam a prática da Nova Ciência em torno dos anfiteatros de anatomia. Cada um desses centros estava associado a cientistas de reputação internacional, que haviam contribuído para o progresso da nova ciência e feito importantes descobertas: Delft estava ligada aos nomes de Reinier de Graaf e Antoni van Leeuwenhoek; Leiden a Johannes Van Horne, Franciscus Deleboe Sylvius, Herman Boerhaave e Bernardus S. Albinus; Amsterdã associava-se a Nicolaas P. Tulp, Frederik Ruysch e Johannes Swammerdam. ${ }^{4} \mathrm{O}$ anfiteatro de anatomia era um dos locais onde se procedia a demonstração e discussão das novas descobertas e experiências. No mesmo prédio realizavam-se aulas semanais de anatomia para aprendizes de cirurgia, estudantes de medicina e parteiras. $\mathrm{O}$ anfiteatro dispunha também de uma biblioteca científica e de um museu onde se exibiam coleções de "curiosidades", ou seja, objetos de história natural e ciência natural. Importantes obras de arte foram produzidas em conexão com o anfiteatro, não só pinturas representando dissecações (como o "Dr. Tulp", de Rembrandt), livros de anatomia como o Anatomia, de Bidloo, ilustrado pelo pintor Gerard de Lairesse, e salas de Anatomia, como a de Ruysch, mas também as pinturas decorativas de Leiden e os interiores de igreja de Delft. ${ }^{5} \mathrm{O}$ anfiteatro era também um museu de arte.

3 Ver J. C. C. Rupp, "Matters of Life and Death: The Social and Cultural Conditions of the Rise of Anatomical Theatres, with Special Reference to the Seventeenth Century Netherlands", History of Science, vol. 28, $\mathrm{n}^{\circ} 81,1990$, pp. 263-87, parte 3.

4 Reinier (Regnerus) de Graaf, Opera Omnia, Leiden, 1677 (em holandês: Alle de wercken, zo in de ontleedkunde als andere deelen der medicynen, Amsterdã, 1686); The Collected Letters of Antoni van Leeuwenhoek. Alle de brieven van Antoni van Leeuwenhoek. Amsterdã, 1939-1979, 10 vols: J. van Horne, Microcosmos seu brevis manuductio ad historiam corporis humani, Leiden, 1660; F. D. Sylvius, Opera medica, Amsterdã, 1630 ( $2^{\mathrm{a}}$ ed., 1679, $3^{\mathrm{a}}$ ed., 1695): H. Boerhaave e B. S. Albinus, Andreae Vesalii, invictissimi Caroli V. Imperatoris medici, opera omnia anatomica \& chirurgia, tomos I-II, Leiden, 1725; Nicolaus Petreus Tulp(ius), Observationum Medicarum, Amsterdã, 1641 (mais tarde, edições ampliadas, Observationes medicae, Amsterdã, 1652, 1672, 1685, 1716); Frederik Ruysch, Opera Omnia anatomica-medico-chirurgica, Amsterdã, 1737, 5 vols. (em holandês: Alle de ontleed-genees-en heelkundige werken, Amsterdã, 1744, 3 vols.); J. Swammerdam, Tractatus physico-anat.-medicus de respiratione usuque pulmonum, Leiden, 1667; J. Swammerdam, Historia insectorum generalis, Leiden, 1669; J. Swammerdam, Miraculum naturae, sive uteri muliebris fabrica, etc., Leiden. 1672; J. Swammerdam, Ephemeri vita of afbeeldingh van's menschen leven, vertoont in de wonderbaarlijcke en nooyt gehoorde historie van het vliegent ende een-dagh-Levent haft of oever-aas. Leiden, 1675; J. Swammerdam, Biblia naturae (Bijbel der Natuure), editado por H. Boerhaave e H. D. Gaudius, Leiden, 1737/1738, 3 vols.

5 O quadro de Rembrandt, "A Lição de Anatomia do Dr. Tulp” (1632) está no Museu Mauritshuis 
Esses anfiteatros eram centros culturais abertos ao público. A dissecação do cadáver de um criminoso realizava-se na época do Natal diante de uma platéia de 300 a 600 pessoas, formada por funcionários do governo, médicos, cirurgiões, estudantes e outras pessoas interessadas. A dissecação, que podia durar várias semanas, seguia uma programação especial na qual se incluíam experiências com animais vivos. O museu, a biblioteca e o jardim botânico também eram abertos ao público. Mas o interesse maior, em todas as camadas da população, convergia para as demonstrações de anatomia e para as coleções de arte.

Este artigo discute a importância da anatomia no surgimento da ciência moderna. Muitos estudiosos da ciência supõem que a religião e, em geral, a moralidade, se opunham fortemente à anatomia. Nesse caso, torna-se difícil explicar por que a anatomia e os anfiteatros a ela associados, puderam alcançar tamanha importância. A tese de Michel Foucault, a meu ver extremamente valiosa, afirma, porém, que a religião e a moralidade não foram obstáculos; o que houve foi um antagonismo entre dois discursos médicos, o da clínica (do lado da vida) e o da anatomia (do lado da morte). ${ }^{6}$ É essa tese que coloco em questão neste artigo mediante a análise dos discursos e das regulamentações da anatomia na Itália, Holanda, Inglaterra e França pré-modernas.

de Haia; G. Bidloo, Anatomia humani corporis, centum et quinque tabulis per artificiosissimum G. de Lairesse ad vivum delineatis illustrata, Amsterdã, 1685 (em holandês: Ontleding des Menschelyken Lichaams. Gedaan en beschreeven door Govard Bidloo. Uitgebeeld, naar het leeven, in honderd en vijf aftekeningen, door de heer Gerard de Lairesse. Amsterdã, 1690). A conferência inaugural de Bidloo, em 1688, em Haia, está incluída na edição holandesa como uma Introdução. F. Ruysch, Museum Anatomicum Ruyschianum sive catalogus rariorum. Amsterdã. 1691 ( $2^{\text {a }}$ ed., 1721, $3^{\text {a }}$ ed.. 1737); F. Ruysch, Thesaurus Anatomicus. Amsterdã, 1702 1716. 10 vols. Para os pintores de Leiden, ver I. Bergström, Dutch Still-Life Painting in the Seventeenth Century. Londres, 1956, pp. 154-90; Cornelis de Man, The anatomical lesson of Dr. Cornelis's Gravesande (1681, Oude en Nieuwe Gasthuis at Delft). De Man participou de um grupo chamado "Os Pintores de Igreja de Delft". Entre eles. Carel Fabritius e, mais tarde, Johannes Vermeer, fizeram experiências com perspectiva e lentes de vários focos, como a teleobjetiva e a grande-angular. Ver A. K. Wheelock. Perspective, Optics and Delft Artists around 1650, Nova Iorque, 1977; J. M. Montias, Artists and Artisans in Delft. Princeton, 1982: W. A. Liedtke, Architectural Painting in Delft, Doornspijk, 1982; Dutch Church Painters. Saenredam's "Great Church at Haarlem" in context. National Gallery of Scotland, Edinburgo, 1984; J. M. Montias, Vermeer and his Milieu. A Web of Social History, Princeton, 1989, Os pintores de Delft eram a vanguarda do século XVII.

6 Ver M. Foucault, La Naisance de la Clinique: Une Archeologie du Regard Medical, Paris, 1963: M. Foucault, The Birth of the Clinic, An Archeology of Medical Perception. Londres, Routledge, 1973, pp. 124-48; M. Foucault, O Nascimento da Clínica, Rio de Janeiro. Forense-Universitária, 1980. 


\section{A religião e o aparecimento da anatomia moderna ${ }^{7}$}

Além dos astrônomos e dos matemáticos, os médicos tiveram grande importância no surgimento da ciência moderna. Na medicina, o desenvolvimento do ensino da clínica (prescrição de dietas, administração de remédios) e da anatomia (cirurgia) desempenhou um papel crucial. Na literatura da história da ciência predomina a opinião de que o desenvolvimento das ciências, em geral, foi muito lento desde os escritos de Hipócrates e Galeno na Antiguidade. Os textos originais dos estudiosos clássicos, gregos e árabes, só se tornaram disponíveis no século XV, quando foram retraduzidos e divulgados, principalmente nas universidades italianas de Bolonha e Pádua. $\mathrm{O}$ ensino da clínica (à cabeceira do doente) e da anatomia teve intenso desenvolvimento em Pádua. A grande edição completa, em latim, das obras de Galeno apareceu em 1541, dois anos antes do De Fabrica Corporis Humanae de Andreas Vesalius, que é considerado o verdadeiro ponto de partida da medicina moderna. Para essa obra, Vesalius "reviu e praticamente reescreveu a tradução dos três tratados de Galeno". 8

Vesalius, um professor de anatomia de Pádua, foi, depois de Modino, o primeiro estudioso da medicina a realizar uma dissecação pública com suas próprias mãos e a basear seu conhecimento anatômico na observação direta. Dessa maneira, descobriu inúmeros erros nos livros de Galeno, que, provavelmente, apenas fizera dissecações de macacos e porcos. O símbolo dessa diferença, conforme entendia o próprio Vesalius, é a dissecação do braço. ${ }^{9}$ Vesalius rompeu conscientemente com a tradição que se desenvolvera nos

7 Uma importante literatura nesse campo é constituída por: B. Farrington, "The Last Chapter of the De Fabrica of Vesalius". Transactions of the Royal Society of South Africa, vol. 20, 1932. pp. 1-14; F. J. Cole, A History of Comparative Anatomy. From Aristotle to the Eighteenth Century, Londres, 1944; C. Singer. Vesalius on the Human Brain, Londres, 1952; W. S. Heckscher, Rembrandt's Anatomy of Dr. Nicolaas Tulp. An Iconological Study, Nova Iorque, 1958: C. D. O'Malley, Andreas Vesalius of Brussels, Los Angeles, 1964, pp. 1-20, incluindo uma traduçāo do Prefácio do De Fabrica de Vesalius de 1543, pp. 317-24: L. Edelstein. Ancient Medicine, organizado por Owsei e C. L. Temkin, Baltimore. The Johns Hopkins Press, 1967; M. Foucault, The Birth of the Clinic..., op. cit.; A. B. de Vries et alli, Rembrandt in het Mauritshuis, Alphen aan de Rijn, 1978, p. 94f; J. J. Bylebyl, "The School of Padua: Humanistic Medicine in the Sixteenth Century", in C. Webster, org., Health, Medicine and Mortality in the Sixteenth Century. Londres, 1979, pp. 335-70; D. L. Hodges, Renaissance Fictions of Anatomy, Amherst, 1985.

8 B. Farrington, "The Last Chapter...", op. cit., p. 1.

9 A. Vesalius, Epistola de radicis chynae decocto, Basiléia, 1546 (em holandês: Brief behelzende de aanwending van het decoct van chynawortel, Amsterdā, 1915). Opuscula selecta neerlandicorum de arte medica III. Ver Brief chynawortel, p. 70 (tradução de minha autoria). 
séculos anteriores, quando a dissecação era praticada por um cirurgião de segunda classe (um cirurgião-barbeiro), enquanto uma pessoa narrava, mediante um texto escrito por Galeno, o que o cirurgião executava. O professor de anatomia, no mesmo dia ou no dia seguinte, fazia sua preleção filosófica. ${ }^{10}$ As dissecações eram realizadas principalmente em corpos de criminosos nas demonstrações públicas iniciais, e também em outros cadáveres, quando ocorria um problema legal (como uma suspeita de assassinato por envenenamento) ou um problema médico (para determinar a causa da morte; as dissecações eram feitas até nos cadáveres de papas). Após a sessão de anatomia no cadáver do criminoso, ou até mesmo durante esta, fazia-se a dissecação e vivissecção de animais (nas páginas de rosto de muitos livros de anatomia vêem-se cachorros e macacos). Com o tempo, o anfiteatro de anatomia ganhou uma sede permanente. Um dos primeiros teatros foi criado em Pádua, seguindo-se o de Leiden (1579). ${ }^{11}$

Estudiosos da medicina têm atribuído a causa da longa "estagnação" dessa ciência, especialmente da anatomia, a uma suposta atitude negativa da Igreja diante da retalhação de cadáveres, principalmente humanos. A explicação é que todas as religiões consideram o cadáver como sagrado. C. D. O’Malley, por exemplo, formula essa opinião em relação ao Renascimento e ao início da Era Moderna. O mesmo argumento é usado para explicar as inúmeras reclamações sobre a escassez de cadáveres para os anatomistas a partir do século XV. ${ }^{12}$ Opinião semelhante é encontrada no século XVII:

10 Durante séculos têm sido usadas traduções (em latim) de traduçōes (em árabe) dos textos clássicos gregos, e traduções para o latim de textos originais árabes. Os textos gregos, além disso, foram em grande parte publicados na forma de um comentário, os chamados articella. Ver P. M. Jones, Medieval Medical Miniatures, Londres, 1984, pp. 23-4. A leitura realizada durante as dissecações era, em parte, puramente simbólica. Pode-se dizer que, de modo geral. os novos cientistas tomavam uma atitude de descrença em relação ao que estava escrito. acreditando apenas em suas observaçōes. Simon Stevin pensava que as observações sobre as quais se basearam as obras clássicas estivessem perdidas. Ver S. Stevin, De Wysentyt. 1608: The Age of the Sages, in The Principle Works of Simon Stevin, vols. 1-5. Amsterdã, 1955-1966, p. 593.

11 Ver E. A. Underwood, "The Early Teaching of Anatomy at Padua with Special Reference to a Model of the Anatomical Theatre", Annals of Science, 1963, vol. 19, pp. 1-26; H. J. Witkam. Iets over Pieter Paaw en zijn Theatrum Anatomicum en over het bouwen van de anatomieplaats en de blibliotheek. Leiden. 1967: Th. H. L. Scheurleer. "Un amphitéâtre d'anatomie moralisée". in Th. H. L. Scheurleer e G. H. M. Posthumus Meyjes, eds., Leiden University in the Seventeenth Century. An Exchange of Learning, Leiden, 1975, pp. 217-77, nota $n^{\circ} 11$.

12 Ver G. Richter, Das Anatomische Theater [Abhandlungen zur Geschichte der Medizin und Naturwissenschaft Heft 16. Berlim. 1936 (nova edição em 1977)], p. 23; C. D. O'Malley, Vesalius, pp. 100, 113, 117-8, 200-1. 
"Em tempos remotos, por mais que uma pessoa fosse corajosa e inteligente, e por mais que tivesse inclinações pelo saber e a arte da anatomia, ela não poderia ter feito muito, porque os cadáveres eram considerados sagrados e as mãos que os tocavam eram tidas como contaminadas; é por isso que a religião extremamente piedosa dos antigos estabelecia tantos rituais de limpeza, aspersão e cerimoniais de purificação". 13

Em um recente livro de anatomia medieval, ${ }^{14}$ Marie-Christine Pouchelle ressalta em tom dramático:

"É bastante conhecido que na Idade Média a retalhação de cadáveres em busca de conhecimento estava submetida a tabus profundamente enraizados na mentalidade da época. Não se podia aceitar - e será que, ainda hoje, se aceita totalmente fora dos círculos estritamente científicos? - que, em nome da ciência, fosse dado a alguém o direito de invadir um corpo morto, um microcosmo habitado pela alma, ou de dissecar com uma faca invasiva as partes mais íntimas de uma pessoa."

E, acrescenta Pouchelle: "Se o anatomista violava a integridade de um cadáver, o cirurgião sentia como se as forças vitais do corpo, e até mesmo a alma, escorressem entre seus dedos junto com o sangue". 15

Pouchelle, entretanto, não encontra nenhuma indicação na obra do anatomista medieval francês Mondeville, personagem central de seu livro, que ateste a existência do suposto tabu religioso contra a dissecção.

De acordo com Ludwig Edelstein, diversos testemunhos afirmam, sem deixar margem a dúvidas, que a dissecação não só era praticada na Idade Média, mas que também os médicos da Alexandria faziam dissecações e vivissecções em seres humanos por volta do início da nossa Era. No entanto, a maioria dos estudiosos afirma que:

"Na Grécia a dissecação era totalmente impensável. Acreditava-se que conceitos religiosos e mágicos, a veneração do morto e a reverência ao cadáver teriam tornado impossivel a dissecação. Da mesma maneira, a vivissecção era impensável por razões humanitárias. Relutava-se em atribuir aos médicos, pessoas que socorrem, tamanha crueldade. Afirmava-se que os relatos de dissecação e vivissecção eram mentiras iníquas criadas por uma escola para difamar a outra." 16

Não se acreditava na veracidade dos relatos, porque

13 G. Bidloo. Ontleding des menschelyken..., op. cit.. p. 4 (tradução minha). O mesmo raciocínio pode ser encontrado nos livros do século XIX sobre a história da anatomia. Ver, por exemplo. em A. van der Boon $\mathrm{Cz}$., Geschiedenis der ontdekkingen in de ontleedkunde van den mensch, gedaan in de Noordelijke Nederlanden, tot aan het begin der negentiende eeuw, Utrecht, 1851. passim.

14 M. C. Pouchelle, The Body and Surgery in the Middle Ages. Oxford, Polity Press, 1990, p. 1.

15 Idem, p. 86.

16 L. Edelstein, "The History of Anatomy in Antiquity", in L. Edelstein, Ancient Medicine..., op. cit., pp. 247-301 e 248-9. 
" [...] para os antigos a reverência pelos mortos era um dever imperioso. Todos tinham o dever de zelar para que um cadáver fosse sepultado, e não havia nenhuma outra obrigação maior para os parentes. Como seria possível, então, que os antigos destroçassem cadáveres a fim de descobrir a estrutura dos órgãos humanos[...]. A alma não encontra paz no mundo subterrâneo até que o corpo esteja enterrado em segurança. Seu repouso não deve ser perturbado jamais." 17

$\mathrm{Na}$ opinião de Edelstein, saber se era possível ou não realizar dissecações e vivissecções não dependia das idéias sustentadas pelas "massas supersticiosas", mas do discurso das pessoas cultas e dos cientistas. Contrariando sua própria tese, porém, Edelstein afirma, relativamente a uma época anterior, que os médicos dos tempos de Homero não praticavam a dissecção porque a pesquisa

" [...] ]em nome da ciência era uma concepção ainda ausente na mentalidade ingênua das pessoas, e, sobretudo, porque o respeito pelo morto e a reverência pelos cadáveres eram, então, fortes demais para que se ousasse importuná-los. Podia-se oferecer um sacrifício humano ao deus, se ele assim o exigisse, podia-se deixar insepulto o corpo de um inimigo ou de um criminoso, mas ninguém podia forçar sua própria natureza a ponto de abrir um corpo sem vida. Foi necessário um longo desenvolvimento antes que a resistência religiosa e mágica fosse superada e até que as dissecções se tornassem, em determinado momento, factíveis. ${ }^{18}$

\section{A tese de Foucault}

A principal tese de Ludwig Edelstein é que a demanda por cadáveres dependia do discurso médico, do progresso da ciência e da educação, e que a provisão de corpos dependia do interesse do Estado na medicina.

“Apesar de todos os obstáculos, até mesmo os médicos medievais puderam obter, por meio da intervenção do Estado ou do roubo, os cadáveres necessários para as dissecações. Pelos mesmos caminhos, eles conseguiram fazer dissecações durante o Renascimento e a Época Moderna. Portanto, também não era impossível realizá-las na Grécia. Deve-se acrescentar que as dissecações não eram mais freqüentes na Grécia do que no início do Renascimento, e na Idade Média talvez fossem ainda mais raras. Isso parece decorrer do fato de que a necessidade de dissecações não era universalmente reconhecida. Apenas a Escola Dogmática de Alexandria insistia nelas; as escolas empirista e metodista as rejeitavam."

17 L. Edelstein, Ancient Medicine..., op. cit., p. 273.

18 Idem, pp. 252-3. 
O ensino era ministrado em grande parte por demonstração e não necessitava de muitos corpos. ${ }^{19}$

Em seu clássico, O Nascimento da Clínica, ${ }^{20}$ Michel Foucault formula a hipótese de que não foram a religião ou a Igreja que impediram o desenvolvimento da anatomia de cadáveres, mas sim o que ele chama de "discurso clínico", que, em sua opinião, predominou na medicina até o final do século XVIII.

"Para o século XVIII e para toda uma tradição já familiar ao Renascimento, o conhecimento da vida se apoiava na essência do ser vivo, pois este é apenas uma de suas manifestaçōes. É por isso que só se procurava ${ }^{21}$ pensar na doença a partir do ser vivo ou de seus modelos (mecânicos) e seus constituintes (humorais, químicos); tanto o vitalismo quanto o antivitalismo nasceram dessa anterioridade fundamental da vida na experiência da doença." 22

No final do século XVIII, com Bichat e outros, formulou-se um discurso inteiramente contrário (o da medicina anátomo-clínica), implicando uma ruptura epistemológica, no sentido de que apenas à morte a doença e a vida dizem sua verdade. Até então a doença era vista como algo mau que assaltava o corpo de fora; a morte era o oposto da vida. Em outras palavras, enquanto os olhos dos médicos se voltavam para a eliminação da doença, para a cura, para a vida, a morte era vista como a ameaça negra que anulava seu saber e habilidade, era o fracasso da medicina. Ao contrário, para Bichat e Morgagni, entre outros, "o conhecimento da vida encontra sua origem na destruição da vida e em seu extremo oposto: é à morte que a doença e a vida dizem sua verdade". ${ }^{23}$ Esse ponto de ruptura epistemológico é atribuído à descoberta de Bichat de que:

"A natureza trabalha com materiais extremamente simples, com base apenas nos tecidos. Estes são os elementos dos órgãos, atravessam-nos, ligam-nos uns aos outros e constituem amplos 'sistemas' acima desses órgãos, nos quais o corpo humano encontra as formas concretas de sua unidade." 24

Alterações nos tecidos (dos órgãos) do corpo humano são causas de doenças e, ao mesmo tempo, manifestações do processo de morte. A dissecação anatômica (dos tecidos) do cadáver é necessária para o verdadeiro

19 Idem, p. 299.

20 M. Foucault, Birth of the Clinic..., op. cit., pp. 124-48.

21 Na tradução inglesa a expressão "mais do que" foi omitida.

22 M. Foucault, Birth of the Clinic.... op. cit., p. 145. Por exemplo, P. Huard e M. Drazen Grmek, La Chirurgie Moderne. Paris, 1968, p. 10.

23 M. Foucault, Birth of the Clinic..., op. cit., p. 145.

24 Idem, p. 128. 
conhecimento da doença e da morte. Previamente a esse ponto de inflexão epistemológica, a anatomia orientava-se para a localização da doença na geografia do corpo humano, enquanto os clínicos se concentravam na história dos sintomas da doença na superfície do corpo e na classificação dos sintomas correlatos em um sistema de doenças.

"A doença não é mais um amontoado de caracteres espalhados aqui e ali ao longo da superfície do corpo humano, unidos por coincidências e sucessões estatisticamente observáveis; é um conjunto de formas e deformaçōes, figuras e acidentes, e de elementos deslocados, destruídos ou modificados, unidos em seqüência de acordo com uma geografia que pode ser seguida passo a passo. Não é mais uma espécie patológica que se insere no corpo onde for possível: é o próprio corpo que se torna doente. $" 25$

Quando se generalizou a percepção de que a anatomia patológica é fundamental para a medicina, criou-se toda uma mitologia justificadora de que as novas concepções teriam sido obstadas pelas antigas crenças religiosas e morais e que os médicos sempre tiveram "no fundo de seu apetite científico a necessidade reprimida de abrir cadáveres". ${ }^{26}$ Esse mito inclui também os boatos acerca do roubo de cadáveres como prática de Vesalius e dos anatomistas em geral. Foucault afirma que, no século XVIII, os anatomistas e os clínicos não tinham dificuldade alguma para encontrar cadáveres.

\section{Os discursos médicos}

De que tipo de provas se dispõe hoje acerca da questão de a religião ter sido ou não um obstáculo para o desenvolvimento da anatomia? Em primeiro lugar, pode-se dizer que houve uma estagnação não só da anatomia, mas também da astronomia e da matemática. ${ }^{27}$

A grande polêmica entre Vesalius e seu antigo mestre Sylvius girava em torno da questão de se o primeiro tinha "acusado" Galeno, com razão ou não, de ter feito a dissecação de cadáveres humanos. ${ }^{28}$ Por mais séria que

25 Idem, p. 136.

26 Idem, p. 126.

27 Há dúvidas sobre o uso do termo "estagnação" para caracterizar aquele período. Ver L. Edelstein, "Recent Trends in the Interpretation of Ancient Science", in L. Edelstein, Ancient Medicine..., op. cit., pp. 401-40.26 As coleçōes expostas nos museus dos anfiteatros, os livros escritos por anatomistas e as conexões entre médicos e demais cientistas em torno dos anfiteatros, dão provas de que os anatomistas e os médicos encaravam suas atividades como parte da Nova Ciência, comparando seu trabalho com o dos astrônomos, geógrafos, matemáticos e físicos. Não se encontrou até hoje um só documento governamental que tenha declarado proibida a dissecação. 
tenha sido a polêmica, tanto um quanto outro consideravam a dissecação de corpos humanos bastante natural e inquestionável. Vesalius mencionou Aristóteles e Hipócrates como anatomistas que dissecaram corpos humanos, de modo que também se pode falar da existência de um conflito de opiniões, na Antiguidade, a respeito da utilidade da anatomia de cadáveres humanos para a medicina, para a cura de doenças. A autópsia era uma prática regular. como já dissemos.

$\mathrm{O}$ que se pôde encontrar foram documentos de regulamentação da dissecação que apontavam para uma prática já existente. Os primeiros documentos conhecidos de regulamentação da anatomia pública datam do início do século XIV. ${ }^{29}$ Os primeiros registros dando conta da existência dos anfiteatros de anatomia são do começo do século XVI. ${ }^{30}$ Heckscher menciona um desses documentos no livro de Alessandro Benedetti (Benedictus), Historia Corporis Humani sive Anatomice, editado em 1497, em Veneza. Esse médico de Verona escreveu no livro I, capítulo i (tradução de Heckscher): Dos usos das anatomias públicas, a seleção de um cadáver e dos preparativos $^{31}$ de um anfiteatro temporário.

“Chegou até nós que os próprios reis. preocupados com o bem-estar geral, retiravam criminosos da cadeia e dissecavam-nos vivos, com o intuito de sondar os segredos da natureza e de suas sutilezas internas enquanto a consciência ainda estivesse presente localização, cor, forma, tamanho, organização, desenvolvimento e deterioração dos órgãos, muitos dos quais sofrem mudanças no corpo morto - e para que pudessem fazer observações precisas em vez de reverentes[...].

Mas nossa religião proíbe essa prática, porque ela é de extrema crueldade e agravada pela repulsão ao torturador, e porque morrer no desespero de tais tormentos significa a deplorável perda da esperança numa vida futura. Deixemos esses costumes aos bárbaros e estrangeiros que os inventaram e que têm prazer nessas malvadezas e ofensas. Quanto a nós, poupemos misericordiosamente os vivos e investiguemos os segredos mais intimos da natureza nos cadáveres dos criminosos."

28 Ver A. Vesalius, Brief chynawortel..., op. cit., p. 37f.

29 G. Richter, Das Anatomische Theater..., op. cit., pp. 14 e 28-9; M. C. Pouchelle, The Body and Surgery..., op. cit., pp. 25 e 83. Em 1655, Amsterdã obteve de Felipe II a prerrogativa de realizar, anualmente, uma demonstração pública de anatomia feita sobre o cadáver de um criminoso executado. Ver A. B. de Vries et alli, Rembrandt..., op. cit., p. 94.

30 Ver G. Richter, Das Anatomische Theater ..., op. cit., pp. 26-7.

31 W. S. Heckscher, Rembrandt's Anatomy of..., op. cit., pp. 182-3. Na tradução de Heckscher "instalado", em vez de "temporário", dá a impressão errada de que o anfiteatro já era permanente. Ver G. Richter, Das Anatomische Theater..., op. cit., p. 24; Th. H. L. Scheurleer, "Un amphitéâtre...", op. cit., p. 11 . 
Nesse documento, afirma-se que a Igreja proibia a vivissecção de seres humanos. Os "bárbaros" são acusados de fazê-la em criminosos, e uma prática já existente de anatomia pública de cadáveres de prisioneiros aparece como tendo sido regulamentada meio século antes de Vesalius publicar seu famoso livro. O motivo da vivissecção de seres humanos (criminosos) era pesquisar as formas mais essenciais da vida (os segredos da natureza enquanto a consciência está presente), mas esse tipo de prática era, ao mesmo tempo, encarado como destruidor da essência da vida e nocivo para a reputação dos juízes/reis e para os carrascos.

Edelstein relata testemunhos de que os médicos de Alexandria realizavam dissecação e vivissecção de seres humanos. Essas práticas começaram no século III a.C. e ainda eram possíveis no século II da Era Cristã. Na opinião da Escola Dogmática, influenciada por Aristóteles, as dissecações eram úteis porque ensinavam dados morfológicos, mas a verdadeira substância da vida não podia ser descoberta dessa maneira.

"Um homem morto ainda retém a mesma forma corpórea, mas já não é um ser humano. Portanto, o que é importante no ser vivo não pode ser a forma, que permanece na morte. embora a verdadeira substância da vida tenha desaparecido.,"32

O conhecimento do ser humano vivo é de fundamental importância. Se a natureza do homem muda com a morte, a vivissecção é certamente necessária. A Escola Empirista, no entanto, rejeitava como desnecessária a dissecação e a vivissecção, pois tudo o que se deve saber sobre o homem pode ser aprendido a partir do sujeito vivo durante o tratamento. Além disso, a vivissecção não pode ser bem-sucedida, porque um ser humano morre quando é cortado pela faca. Em Alexandria, a vivissecção era praticada nos cadáveres de criminosos. Na opinião de Edelstein: "dessa maneira, a decisão a ser tomada entre dissecação e vivissecção também se transforma de um problema estritamente médico em uma questão filosófica e científica".

\section{Andreas Vesalius}

No Prefácio de seu livro De Fabrica, Vesalius declara que os doutores foram os responsáveis pelo declínio da medicina, pois não realizavam mais o trabalho prático de cuidar, ministrar remédios e operar. Mas essa não pode ser a razão pela qual Galeno não dissecava cadáveres humanos - ele reali-

32 L. Edelstein, Ancient Medicine..., op. cit., p. 290. 
zava dissecações e vivissecções em corpos de animais com as próprias mãos. O problema parece ser de natureza essencialmente epistemológica.

A vivissecção de animais era uma prática usual no tempo de Galeno. Este se recusava apenas à dissecação dos órgãos sexuais de animais vivos e "parece que evitava operações repugnantes quando realizava vivissecções públicas". ${ }^{33}$ No seu tempo, a vivissecção de seres humanos já tinha sido proibida há muito. Sabe-se que Vesalius subtraiu alguns trechos da $2^{\mathrm{a}}$ edição do De Fabrica porque recordavam a vivissecção. ${ }^{34}$ Para ele, a vivissecção de animais não estava em questão. No final de todas as sessões públicas de anatomia de um cadáver (de criminoso), Vesalius fazia a vivissecção de um ou mais animais, repetindo basicamente experiências de Galeno: o primeiro ato destinava-se a demonstrar a estrutura do corpo humano; o segundo, a examinar o funcionamento de partes do corpo (vivo). A vivissecção tem, ademais, utilidade para a prática cirúrgica. ${ }^{35}$ Vesalius realizava experiências, mediante a vivissecção de animais, a respeito do funcionamento do coração, dos pulmões, da voz ("É melhor escolher uma porca por causa da voz. Pois um cachorro, depois de amarrado por um certo tempo, a despeito do que se faça com ele, no fim já não late ou uiva e, portanto, não se pode observar a perda ou enfraquecimento da voz") ${ }^{36}$ de fetos etc. Mas Vesalius não fazia experiências com as funções do cérebro.

"Pois bem, muito pouco pode ser observado acerca do cérebro e suas funções através da vivissecção, posto que neste assunto, quer se queira ou não, mas apenas em respeito aos nossos teólogos nativos, nos sentiríamos mais culpados pela privação da memória, da razão e do raciocínio de criaturas brutas, já que sua estrutura é a mesma dos humanos. ${ }^{37}$ Assim, o estudante de anatomia e aquele que tem experiência na dissecação de cadáveres, se não estão contaminados pela heresia, compreendem claramente os

33 N.A. Rupke, ed. Vivisection in Historical Perspective, Londres, 1987, p. 16. Anita Guerrini, "The Ethics of Animal Experimentation in Seventeenth-Century England". Journal of the History of Ideas, vol. 50, $\mathrm{n}^{\circ} 3,1989$, pp. 391-407.

34 C. D. O'Malley, Andreas Vesalius..., op. cit., p. 101.

35 A. Vesalius, De Fabrica.... op. cit., p. 658. Ver, por exemplo, B. Farrington, "The Last Chapter...", op. cit. Em 1538, Vesalius, convidado por estudantes, dissecou três cadáveres humanos e seis cachorros no anfiteatro de Bolonha erguido dentro de uma igreja. C. D. O'Malley, Andreas Vesalius..., op. cit., pp. 98-9.

36 B. Farrington, "The Last Chapter...”, op. cit., p. 10. Hieronymus Fabricus Ab Aquapendente foi o mais importante sucessor de Vesalino na experimentação. Ver seu livro Opera Omnia Anatomica et Physiologica, Leiden, Editio Novissima, 1738.

37 Na tradução de Farrington está escrito "embora sua estrutura [...]", mas está errado. . "[...] in cerebri igitur ipsius, partium examine, parum omnino in viva sectione videndum est, quum hic velimus nolimus, vel theologorum nostratium causa, memoriam, rationem \& cogitationem brutis animalibus adimere debeamus, utcunque illis cum homine eadem sit constructio". 
riscos aos quais eu me exporia se fizesse qualquer tentativa de vivissecção do cérebro - coisa que. em outras circunstâncias, eu faria de bom grado. Entretanto, no que diz respeito aos sentidos e ao movimento, é possível observar que ambos perecem quando se remove o cérebro. E. nesse caso, deve ser empregado o mesmo método de experimentação que prescrevi para o trato dos nervos. De fato, a questão de se o cérebro tem sensação pode ser investigada no homem. posto que um homem cujo cérebro é cortado ou comprimido pode dizer se sente dor ou tem qualquer outra sensação no ponto em que o cérebro é tocado." 38

No âmbito do debate sobre a essência da vida, tanto Vesalius quanto Galeno e Aristóteles diferenciam entre "o espírito vital" (os intestinos), "o espírito natural" (o coração) e "o espírito animal" (o "princeps anima"). Na concepção de Vesalius, o "espírito animal" é a essência da vida na medida em que concerne à "memória, raciocínio e pensamento", enquanto "os movimentos e sensações" também fazem parte da vida dos irracionais ("criaturas brutas"). A vivissecção de animais permite descobrir todas as funções do corpo humano, inclusive, até certo ponto, as do cérebro (movimentos e sensações), mas não as da "memória, pensamento e raciocínio". ${ }^{39}$ Embora Vesalius tenha detectado diversos erros na descrição que Galeno fez da estrutura do corpo humano, ele não se distingue deste em uma questão central, a da importância das experiências de vivissecção; e também não difere de Galeno na opinião de que os cérebros dos animais só se diferenciam dos do homem pelo tamanho. Havia uma concepção geral de que as faculdades do pensamento, memória e razão, situavam-se em um dos ventrículos do cérebro, opinião que se chocava com a constatação de que os cérebros dos animais têm a mesma estrutura do dos humanos, mantida a crença de que o homem é diferente dos animais; estes também têm uma "alma", posto que o princeps anima se refere aos movimentos e sensações.

No discurso de Vesalius acerca da vida, doença e morte, tudo se destina à vida e a viver, e quase tudo toca o que consiste, a seu ver, na essência da vida humana (pensamento e demais funções). Mas a dissecação do cérebro de animais é proibida e, mais fundamentalmente, insuficiente, no que diz respeito a essas funções do cérebro.

A retalhação de cadáveres como meio de delinear a estrutura e as proporções do corpo era considerada útil na medicina renascentista. especialmente para a cirurgia. Foi Vesalius quem descobriu que o conhecimento da geografia do corpo humano exigia uma comparação (epistemológica) entre a

38 B. Farrington, "The Last Chapter...". op. cit., p. 10.

39 C. Singer, Vesalius on the Human..., op. cit., pp. 1, 4 e 40. 
anatomia dos cadáveres humanos e a dos corpos dos animais. A vivissecção de animais era importante para conhecer as funções inferiores do corpo, inclusive movimentos e sensações, mas não necessária. As funções do cérebro, como movimentos e sensações, também podem ser estudadas em seres humanos atingidos por lesões. A essência da vida não pode ser alcançada nem pela anatomia dos cadáveres humanos nem pela vivissecção de animais, que carecem das funções da memória, pensamento e raciocínio.

No século XVII importantes experiências foram feitas com animais vivos, como as de Harvey acerca da circulação sanguínea, de De Graaf sobre o funcionamento do pâncreas e de Boyle com oxigênio comprimido. As experiências de vivissecção eram consideradas como as mais importantes pesquisas médicas, e o discurso médico dominante ainda era "clínico". Harvey fixou suas prioridades com toda a clareza em uma carta a Jo. Riolan, por ocasião da publicação, em 1648, do livro deste último, intitulado Encheiridium Anatomicum et Pathologicum:

"E, com efeito a consideração fisiológica das coisas consonantes com a natureza deve ser, em primeiro lugar, realizada pelos médicos, pois tudo aquilo que é conforme à natureza está certo e serve, via de regra, tanto a si mesmo quanto àquilo que está errado; através da luz que dissemina, também se definem as aberrações e enfermidades contrárias à natureza; a patologia ressalta, então, com mais nitidez; e se percebe, a partir da patologia, os usos e a arte da cura, bem como as oportunidades de descoberta de muitos remédios".

No contexto da patologia ele ousa afirmar que:

“[...]o exame de um único corpo de alguém que morreu de tabes dorsalis ou outra doença de longa duração, ou de natureza venenosa, é mais útil à medicina do que a dissecação dos corpos de dez homens mortos por enforcamento". 40

Mas, no último quarto do século XVII, ganhou terreno o que Foucault denominou de discurso anatômico. A escola de anatomia de Amsterdã, por exemplo, persistia na sua busca da essência da vida nos cadáveres humanos. Frederik Ruysch (que tinha ojeriza à vivissecção animal) aproximou-se bastante da descoberta de Bichat de que o tecido é o elemento básico e fundamental da vida humana.

40 The Works of William Harvey, traduzido do latim por R. Willis, Londres, 1847, p. 91. Primeiras edições: W. Harvey, Exercitatio anatomica de motu cordis et sanguinus in animalibus, 1628: W. Harvey, De generatione animalium, 1651; W. Harvey, Lectures on the Whole of Anatomy. tradução de C. D. O'Malley et alli, Berkeley, 1961. 


\section{Cadáveres humanos}

Não se encontra nenhum trecho na obra de Vesalius onde ele fale a respeito da escassez de cadáveres humanos (O'Malley e outros apenas sugerem isso). Ele dependia de "patrocinadores", como todos naquela época (os custos de uma anatomia incluíam, em primeiro lugar, o transporte do corpo, os lençóis, os criados utilizados e, apenas secundariamente, o pagamento do anatomista). Um desses patrocinadores foi o juiz Contarini, ${ }^{41}$ que chegava a determinar a hora da execução de criminosos e o modo como deveriam ser mortos em atendimento à vontade de Vesalius. Também não encontrei nenhuma indicação de que faltasse aos doutores cadáveres em número suficiente durante os séculos XVI e XVII, na Holanda. Kroon faz referência a um documento, datado de 1593, no qual os Estados da Holanda e o Friesland Ocidental concediam à Universidade de Leiden o privilégio de que todos os cadáveres de criminosos executados no inverno nos territórios dos dois Estados, fora de Leiden fossem entregues aos professores de anatomia daquela Universidade. ${ }^{42}$ "Se muitas pessoas forem executadas, a que estiver mais próxima deve ser entregue imediatamente." Às vezes era difícil encontrar um criado para levar os cadáveres até Leiden, para limpar o anfiteatro e coisas semelhantes, porque eles eram muito malpagos. Em diversos trechos dos livros dos anatomistas, encontram-se declarações sobre a existência de grande quantidade de corpos disponíveis para dissecação. Thijssen, em 1881, concluía que: "Na Amsterdã do século XVII fazia-se muito menos objeção a abrir cadáveres do que em nosso próprio século tão esclarecido." ${ }^{43}$

$\mathrm{O}$ que os escritos de Vesalius e de cientistas holandeses como de Graaf, Tulp e Ruysch demonstram é uma escassez de tempo para a anatomia, porque, como afirmam, estavam muito ocupados com a prática clínica. Vesalius escreveu em sua Epistola - uma carta em que ele, tendo sido criticado por refutar a autoridade de Galeno, faz um relato de seu trabalho e de seus métodos - que a anatomia é para os anos da juventude, quando ainda não se tem maturidade suficiente para ganhar dinheiro. Em outras palavras, não se pode viver da anatomia, ela não tem status suficiente para

41 A. Vesalius, De Fabrica..., op. cit., p. 650; C. D. O'Malley, Andrea Vesalius..., op. cit., p. 113.

42 J. E. Kroon, Bijdragen tot de geschiedenis van het geneeskundig onderwijs aan de Leidse Universiteit 1575-1625, tese defendida em Leiden, 1911, p. 134.

43 E. H. M. Thijssen, Nicolaas Tulp als Geneeeskundige Geschetst. Eene Bijdrage tot de Geschiedenis der Geneeskunde in de XXVII de Eeuw, tese defendida em Amsterdã, 1881, p. 30. 
tanto. ${ }^{44}$ Vesalius reclamava de ter de fazer dissecações para pintores e escultores, e por isso se sentia mais desgraçado do que a pessoa dissecada.

\section{Conflito de interesses}

Até mesmo Vesalius abandonou sua prática de anatomia para tornar-se médico do imperador, como seu pai e avô haviam feito anteriormente. L. S. Feuer atribui esse fato a sentimentos de culpa evocados por suas dissecções, especialmente de meninas, um modo de pensar que mantém intacto o mito da anatomia. O'Malley procurou levantar um argumento plausível, dizendo que Vesalius tentara deixar os serviços que prestava ao imperador para retomar sua prática anatômica. Esse raciocínio não difere do de Feuer: o anatomista é retratado como um herói dedicado à prática muito penosa da anatomia, vista, no final do século XVIII, como a mais importante de todas as práticas para a humanidade. ${ }^{45}$ Harvey abandonou a anatomia experimental para ser médico do rei; Tulp, em Amsterdã, desistiu da anatomia, mas não de sua prática geral, quando se tornou burgomestre da cidade: o professor Sylvius, de Leiden, escreveu a seu aluno Reinier de Graaf, em Delft, que já não dispunha de tempo para a anatomia porque tinha muitas outras coisas para fazer ${ }^{46}$ Todas essas descobertas apontam mais para a existência de conflitos de interesse (médicos) do que para empecilhos morais e religiosos. ${ }^{47}$

\section{Primeira Discussão}

A anatomia e os anfiteatros de anatomia foram muito importantes na Idade de Ouro holandesa, fato que não encontra fácil conciliação com a tese de que a religião se opunha fortemente a essa prática. O reexame dessa

44 A. Vesalius, Brief chynawortel..., op. cit.. pp. 186-7.

45 L. S. Feuer. The Scientific Intellectual. The Psychological and Sociological Origins of Modern Science, Londres, 1963, pp. 167-82: C. D. O'Malley. Andrea Vesalius.... op. cit.. pp. 289-90. 296 e 307.

46 De Graaf, "Prefácio". in Alle de Wercken.

47 Isso indica também falta de dinheiro. Bidloo não faz segredo de que estava à procura de patrocinadores em Amsterdā, entre "aficcionados da arte. homens famosos por seus cargos e ciência" para provê-lo dos corpos de que necessitava para a elaboração de seu atlas completo da "estrutura" do corpo humano. G. Bidloo, "Prefácio". in Ontleding des Menschelyken.... op. cit. 
questão leva à conclusão de que a Igreja cristã proibia rigorosamente não a dissecação de cadáveres humanos, mas a vivissecção de seres humanos, assim como a dos cérebros de animais. Esse tipo de anatomia poderia destruir a "alma". Para Vesalius e os anatomistas em geral tal preceito moral funcionava como barreira, pois eles almejavam, acima de tudo, conhecer o funcionamento do corpo vivo. Ora, Vesalius demonstrara que a abertura de corpos humanos, comparadas com a de animais, era necessária para alcançar o conhecimento, e distinguira, no interior do princeps anima, entre a parte relativa ao movimento e sensação (também presente nos animais irracionais) e a parte relativa ao pensamento, memória e raciocínio (especificamente humana). Assim, não podia tocar no que, para ele, era a essência da vida (humana). Apesar da proibição da vivissecção do cérebro animal, o movimento e a sensação podiam ser estudados em seres humanos que haviam sofrido lesões. No século XVII, os médicos se interessavam, antes de tudo, por conhecer o funcionamento do corpo (vivo) por meio da experimentação com base em heurísticas derivadas da física (mecânica) e da química. Nesse contexto, as experiências com animais vivos eram tidas como uma fonte necessária de conhecimento.

O discurso clínico sustentou-se até a segunda metade do século XVII, o que corrobora a tese de Foucault da existência de um antagonismo entre as perspectivas clínica e anatômica. As causas das doenças e da morte deviam ser procuradas no corpo vivo, e a morte era o oposto da vida. O conhecimento da estrutura do corpo era muito importante para a cirurgia. Na tradição das autópsias, o anátomo-patologista procurava encontrar as causas no locus da doença, mas este lugar não a explicava. Se um médico tivesse de escolher, ele optava pela prática clínica e não pelo exercício da anatomia. A partir de 1760, contudo, o discurso da anatomia tornou-se cada vez mais importante. A escola de Amsterdã, de Fredrik Ruysch, por exemplo, examinava o cadáver humano em virtude de seu caráter básico, essencial, e chegou muito perto das descobertas de Bichat, feitas no final do século XVIII.

\section{Os regulamentos da anatomia}

Uma segunda fonte de verificação da tese de Foucault encontra-se no conjunto de disposições oficiais que regulamentava a prática da anatomia, o qual reflete opiniões morais e políticas.

A anatomia de cadáveres humanos e as experiências de vivissecção de animais podem ter sido relativamente importantes devido à necessidade de 
se conhecer a estrutura do corpo humano (a posição, proporções dos órgãos etc.). Além disso, eram úteis para a cirurgia. Mas por que razão a anatomia tinha um caráter público? Por que se criou um anfiteatro de anatomia que também era um museu? As duas razões mais importantes parecem ser: que a anatomia tinha de ser de interesse público e precisava ser regulamentada.

Os governos municipais holandeses acreditavam que a anatomia não devia permanecer sob o controle das guildas de cirurgiões, ${ }^{48}$ consideradas injudiciosas e negligentes. Por isso, nomearam diplomados em medicina para a função de anatomistas locais (com o título de "professores de anatomia"), concedendo-lhes o privilégio da dissecação de cadáveres de criminosos. Dessa maneira, a anatomia alcançou um status mais elevado. Além disso, foram proibidas as dissecações realizadas na esfera privada ${ }^{49}$ Havia freqüentes suspeitas (Vesalius, por exemplo) de que os médicos obtinham cadáveres por meios ilícitos, roubando-os ou mandando roubar dos cemitérios e dos patíbulos. O "furto" de cadáveres e ossos dos cemitérios e sua compra e venda eram atividades usuais naquele tempo, ${ }^{50}$ mas eram praticados por criados e estudantes, e não por homens de respeitabilidade. Havia todo um comércio de ossos, esqueletos, peças empalhadas, fortemente estimulado pelo interesse por coleções de história natural. As autoridades tentavam deter essas atividades ilegais que provavelmente estavam na origem de muitas revoltas populares.

A anatomia pública era uma atividade passível de regulamentação e o cumprimento das normas podia ser supervisionado. Muitos documentos atestam que médicos e cirurgiões, de início, só conseguiam cadáveres de criminosos para anatomia se se comprometessem a realizar demonstrações públicas anuais. Durante a segunda metade do século XVII, a anatomia foi-se tornando um assunto da esfera profissional "privada" da classe médica, passando aos poucos a incorporar em seu código as regulamentações públicas mais relevantes ${ }^{51}$ Os médicos puderam, então, receber cadáveres dos hospitais para sua prática particular e para as sociedades eruditas informais, contanto que cumprissem os regulamentos.

A segunda razão para a proibição da prática privada da anatomia e o incentivo da prática pública era que ela devia ter um interesse público dos

48 E. H. M. Thijssen. Nicolaas Tulp.... op. cit., pp. 11 e 14.

49 E. A. Underwood, "The Early Teaching...". op. cit.. pp. 4.7 e 18.

50 J. E. Kroon, Bijdragen tot de..., op. cit., pp. 53 e 134.

51 Por exemplo, o pedido feito por Frederik Ruysch. em 1697, aos inspetores do Collegii Medici em Amsterdã. E. H. M. Thijssen, Nicolaas Tulp.... op. cit.. pp. 27-31. 
pontos de vista político, cultural e moral. Segundo a "Introdução" de 1690 do livro de Govardus Bidloo. Ontleding des Menschlyken Lichaams, a anatomia em Amsterdã era "noodzakelijk, heerlijck en vermakelijk". ${ }^{52} \mathrm{~A}$ anatomia é "necessária" porque é o fundamento de toda a medicina, ela estabelece os limites da medicina. Do contrário, seria difícil fazer cirurgias sem danificar partes sadias do corpo. ou prescrever medicamentos de modo apropriado. A anatomia é "nobre", porque pessoas importantes de Amsterdã sempre se interessaram muito por ela e a praticaram - muitos anatomistas locais tornaram-se burgomestres da cidade. A anatomia é "prazeirosa" porque em nenhum outro lugar se descobrem coisas tão interessantes quanto no corpo humano, coisas ainda mais surpreendentes do que os astrônomos e os geógrafos encontram em suas viagens através do vasto mundo. Bidloo indicou três aspectos que justificaram o interesse público pela anatomia:

- a anatomia desfrutava de um status elevado por causa da relevância que lhe atribuíam as pessoas importantes. Além disso, ela conferia status à cidade como defensora das artes e ciências. Segundo Ferrari, poderia considerar-se esse aspecto como seu interesse cerimonial: ${ }^{53}$

- a anatomia tinha interesse científico, sendo importante para a educação dos cirurgiões, dos estudantes de medicina e das parteiras, contribuindo para o progresso da ciência;

- ela atraía um público amplo por conta da natureza surpreendente e divertida do que se descobria no corpo humano; tinha um interesse cultural geral. embora a platéia se diferenciasse quanto à natureza de seus interesses específicos; alguns escritores (como Ferrari) denominam esse aspecto de "interesse festivo", mas, a meu ver, o termo não é adequado, pois implica que "as pessoas comuns" não teriam um interesse autêntico pela anatomia.

A estes, deve-se acrescentar um quarto interesse: o interesse moral. Em pesquisa anterior, mostrei que uma moralidade vazia predominava nos anfiteatros de anatomia holandeses e em seus museus. ${ }^{54} \mathrm{~A}$ dissecação pública também era uma lição de moral. geralmente lembrando às pessoas a fragilidade da vida humana (homo bulla) e, principalmente, advertindo os cidadãos sobre o destino dos criminosos. Alguns "corpos" eram novamente mostrados ao público quando o esqueleto era suspenso no anfiteatro, portando

52 “necessária, deliciosa e prazeirosa” (N , da T). G. Bidloo. Ontleding des Menschelyken .... op. cit.

53 G. Ferrari. "Public Anatomy Lessons and the Carnival: The Anatomy Theatre of Bologna". Past and Present, vol. 117. 1987. pp. 50-106.

54 J. C. C. Rupp, "Matters of Life..." op. cit. 
tabuletas que diziam, por exemplo, "este é o famoso ladrão Galewaard. quem[...]", um emblema típico da tradicional expulsão da sociedade do criminoso e do crime. Segundo A. W. Heckscher e Bryan S. Turner, as sessões públicas de anatomia eram verdadeiras punições, o criminoso morria uma segunda vez, e a sessão era uma advertência geral aos espectadores. ${ }^{55}$ Heckscher situa a anatomia pública na tradição dos Exempla na esfera da "vivissecção cruel", uma tradição desenvolvida na Idade Média. ${ }^{56}$ Contavam-se diversas histórias sobre a vivissecção como anatomia punitiva e há famosas "ilustrações de justiçamento", como os de Gerard David. ${ }^{57}$ Foucault fala do "teatro" de tortura, suplício e pena capital, mas, surpreendentemente, não menciona os anfiteatros de anatomia e a dissecção pública nesse contexto! ${ }^{58}$

\section{Os regulamentos italianos}

A tese de Heckscher pode ser verificada pelo exame dos regulamentos que regiam as demonstrações públicas de anatomia, como os que são formulados no livro de Alexander Benedictus, de 1497, copiados em muitos outros países:

"Apenas pessoas humildes e desconhecidas, então, e os que vêm de regiōes distantes. podem ser. de pleno direito, reclamados para dissecaçâo, sem ultraje para vizinhos ou parentes. Devem ser escolhidos os que foram estrangulados por enforcamento e que sejam de meia-idade, nem magros nem gordos e de envergadura bastante grande. para que as partes de seu corpo sejam de tamanho mais generoso e possam ser mais claramente visíveis para os espectadores. Além disso, há necessidade da temperatura fria de um inverno rigoroso, senão os cadáveres apodrecem cedo demais. Precisa haver um teatro adequadamente adaptado em um lugar espaçoso e bem ventilado. com fileiras de assentos dispostas como em um anfiteatro, igual aos de Roma e de Verona, e este deve ser suficientemente grande para acomodar confortavelmente todos os espectadores, para que os cirurgiões-barbeiros, que executam a dissecação, não fiqquem muito próximos da multidão. Apenas os que são dotados de grande perícia devem se ocupar da dissecação. A disposição dos lugares deve seguir a ordem da hierarquia. Deve haver alguém encarregado da supervisão e da organização de tudo. Guardas devem ser providenciados para

55 W. S. Heckscher. Rembrandt's Anatomy of..., op. cit.: B. S. Turner. Medical Power and Social Knowledge, Londres, 1987. pp. 28f e 34f: B. S. Turner. "The Anatomy Lesson: A Note on the Merton Thesis"., Sociological Review. vol. 38, n 1, 1990. pp. 1-18.

56 W. S. Heckscher, Rembrandt's Anatomy of..., op. cit., pp. 85-90

57 G. David, "The Judgement of Cambyses" (datado de 1498. Groeningemuseum. Bruges).

58 M. Foucault, Discipline and Punish: The Birth of the Prison. Nova Iorque, 1977. 
controlar a entrada da multidão indisciplinada. Devem ser designados dois atendentes confiáveis que, com o valor das taxas de admissão. forneçam os instrumentos cirúrgicos necessários. O cadáver deve ser colocado no centro do anfiteatro, em cima de um banco bastante alto. em um lugar bastante iluminado segundo a conveniência dos que executam a dissecação. A reunião seguinte deve ser anunciada ao final de cada sessão. para que o trabalho esteja inteiramente completado antes que se inicie a decomposição do corpo." 59

$\mathrm{O}$ anfiteatro de anatomia era considerado na Itália como a melhor prova do cuidado das autoridades para com o bem-estar público ${ }^{60}$ As demonstrações tinham uma platéia maior que a de qualquer outro evento e eram assistidas tanto pelas pessoas mais influentes quanto pelas de menor importância ${ }^{61} \mathrm{O}$ monarca era considerado uma autoridade com poder de vida e morte sobre seus súditos; portanto, tinha também o poder de deixar o cadáver insepulto ou de doá-lo para dissecação. ${ }^{62} \mathrm{~A}$ concepção de um sepultamento digno como uma questão de grande relevância remonta à Antiguidade; não ter esse direito era entendido como gravíssima punição que não se desejava nem mesmo aos piores inimigos. ${ }^{63}$ Não há certeza, porém, de que o povo aceitasse a onipotência do rei. Na Itália, estabeleceu-se que apenas os cadáveres de criminosos de outras cidades poderiam ser dissecados, a fim de evitar a abominação de parentes e amigos da vítima. Posteriormente, os anatomistas passaram a receber cadáveres de súditos nascidos nos marcos da cidade, desde que não fossem "cidadãos honrados". ${ }^{64}$ Além disso, durante

59 W. S. Heckscher. Rembrandt's Anatomy of..., op. cit., pp. 182-3.

60 Richter diferencia entre uma sessāo de anatomia pública ao estilo de Pádua, uma solenidade acadêmico-científica. e o estilo que predominava em Bolonha. um espetáculo de caráter social da academia, realizado durante um festival popular (funzione), diferença que. a seu ver. se refletiu no formato arquitetônico dos locais de realização dos eventos - em Pádua. um antiteatro. em Bolonha. um auditório. G. Richter. Das Anatomische Theater.... op. cit., pp. 56-60. Mas em Leiden, assim como em outras cidades holandesas, onde o anfiteatro foi construido segundo o modelo de Pádua. as sessões de anatomia pública também tinham um aspecto teatral. Pode-se deduzir das descrições feitas naquele tempo, acerca da situação holandesa. que as sessões de anatomia atraiam grandes platéias. Para a situação em Leiden ver J. J. Orlers. Beschrijeinge der Stadt Leyden. Leiden. 1614 (2 ${ }^{\mathrm{a}}$ ed. . 1641). Se a dissecação anatômica do cadáver de um criminoso, como evento público, acontecia na época do Natal, a Páscoa era também ocasião de outro acontecimento público, chamado de "Paasdol". Ver em A. van Hulzen, Utrechtse Kloosters en Gasthuizen. Baarn. 1986, p. 152. Durante a Páscoa, podia-se visitar o hospício para observar os loucos, pagando-se uma pequena taxa de entrada. Essas taxas eram uma importante fonte de renda para os hospícios e uma das razões pelas quais esse costume só foi abolido no final do século XVIII.

61 G. Ferrari, “Public Anatomy Lessons..." op. cit.. pp. 81-2.

62 Idem, p. 60.

63 L. Edelstein. Ancient Medicine..., op. cit., p. 273.

64 G. Ferrari, "Public Anatomy Lessons...". op. cit., p. 
o século XVII celebravam-se missas, em uma capela próxima ao anfiteatro de Bolonha, para as almas daqueles que tinham sido dissecados em público. $\mathrm{O}$ povo e o clero protestavam quando cientistas ou alunos de medicina tentavam conseguir os corpos de pessoas mortas por acidente ou assassinato, infringindo as regras da jurisdição. ${ }^{65}$ Durante aquele século, as autoridades permitiam a dissecação dos cadáveres de pessoas pobres que tivessem morrido em um hospital e de corpos retirados dos cemitérios de indigentes. ${ }^{66}$

As normas formuladas por Benedetti sugerem que a dissecação pública não era de modo algum uma reunião tranqüila. Podia prolongar-se durante semanas; a multidão de espectadores, integrada por pessoas de todos os estratos da sociedade, inclusive jovens, mendigos e monges, freqüentemente atrapalhava o exame detalhado do corpo humano. ${ }^{67}$ Para evitar tumulto e garantir que a demonstração fosse acompanhada com modestia, designavamse supervisores incumbidos de cuidar para que apenas funcionários do governo, médicos e outras pessoas "bem-educadas" assistissem à dissecação, mas isso se mostrou inútil. Em 1596, a entrada no anfiteatro de Pádua era gratuita para que todos pudessem comparecer e acompanhar as lições. Em Bolonha, em 1616, a entrada era gratuita para todos os que quisessem assistir à anatomia. ${ }^{68}$

Os regulamentos italianos incentivavam muito a realização de debates durante as sessões públicas. Em Bolonha, principalmente, onde os aspectos cerimoniais ocupavam um lugar proeminente, a disputatio veio a se tornar o ponto central da reunião. A anatomia freqüentemente dava oportunidade para longos debates filosóficos. $\mathrm{O}$ anfiteatro da cidade manteve-se em funcionamento até a metade do século XVIII. Segundo Ferrari, as demonstrações públicas não tinham grande valor científico: ciência praticava-se nas inúmeras academias eruditas e na esfera privada, onde microscópios e outros instrumentos podiam ser usados.

65 Idem, p. 88.

66 Idem, p. 87.

67 A. Castiglioni. "The Origin and Development of the Anatomical Theatre to the End of the Renaissance", Ciba Symposia, vol. 3. n² 2, 1941, p. 833.

68 G. Ferrari, “Public Anatomy Lessons...". op. cit., pp. 98-9. 


\section{Os regulamentos holandeses}

Regulamentos semelhantes foram criados na Holanda, como os que estabeleceu o governo da cidade de Amsterdã, em 1606. ${ }^{69}$ Eles estipulavam que a dissecação pública do cadáver de um criminoso seria permitida uma vez por ano, no inverno, nas proximidades do Natal. Havia necessidade do frio para evitar a decomposição e a putrefação imediata do corpo. O cadáver podia ser de homem ou de mulher e devia ser de meia idade para possibilitar a anatomia comparativa. O criminoso devia ser proveniente de uma cidade diferente daquela onde se realizaria a dissecação, em consideração aos sentimentos dos amigos e parentes. ${ }^{70}$ Os médicos que iriam praticar a dissecação deviam estar munidos de uma licença; na maior parte dos casos esse privilégio ficava restrito aos membros de uma guilda de cirurgiões ou médicos. Os barbeiros foram os primeiros a receber o privilégio, seguidos mais tarde. por volta do final do século XVI, pelos médicos, os praelectores e os professores.

Os lugares no teatro eram distribuídos de acordo com a hierarquia e a classe. A distribuição dos assentos entre dirigentes, médicos e cirurgiões era uma fonte de conflito - a parte do anfiteatro destinada a um grupo devia ser separada da parte designada ao outro para evitar brigas. Fixou-se um preço de entrada e não se admitiam crianças. Aos espectadores cabia comportar-se de modo ordeiro, e as perguntas deviam ser feitas respeitosamente. Durante as aulas ou os debates relativos à anatomia, não se permitia que a platéia ou os palestrantes fossem perturbados por conversas, risos ou qualquer outro barulho. $\mathrm{O}$ conferencista devia responder às perguntas na reunião seguinte. Tanto na formulação das questões, quanto nas respostas e nos debates posteriores, expressões ridículas ou smadelijkheid (irônicas) deviam ser evitadas, comportando-se todos com polidez e respeito. Segundo Nuyens, essa última regra visava evitar conflitos entre cirurgiões e médicos. ${ }^{71}$. Nenhuma

69 A literatura relevante sobre a regulamentação holandesa inclui: E. H. M. Thijssen, Nicolaas Tulp..., op. cit., pp. 33-44; J. E. Kroon, Bijdragen tot de..., op. cit., pp. 49-50; B. W. Th. Nuyens, Het ontleedkundig onderwijs en de geschilderde anatomische lessen van het Chirurgijnsgilde te Amsterdam, in de jaren 1550-1798. Koninklijk Oudheidkundig Genootschap te Amsterdam, Jaarverslag, 1928, pp. 45-90; W. S. Heckscher, Rembrandt's Anatomy..., op. cit.. pp. 182-87; A. B. de Vries et alli, Rembrandt.... op. cit.. p. 219; H. L. Houtzager. Medicyns. vroedwyfs en chirurgyns. Schets van de gezondsheidszorg in Delft en beschrijving van het Theatrum Anatomicum aldaar in de 16e en 17e eeuw. Amsterdã, 1979.

70 E. H. M. Thijssen, Nicolaas Tulp.... op. cit., pp. 38-9.

71 B. W. Th. Nuyens, Het ontleedkundig onderwijs..., op. cit., p. 56 
peça do cadáver dissecado podia ser retirada do local. sob pena de multa; durante a aula, as peças eram passadas pela platéia, de modo que todos, inclusive os espectadores das fileiras mais altas do anfiteatro, pudessem observá-las; essas peças eram depois muito disputadas para montagem de um esqueleto ou para empalhamento. ${ }^{72}$

Os restos mortais do corpo deviam ser enterrados com os devidos cuidados. Essa norma era crucial. Sabe-se, por exemplo, que em Franeker as autoridades relutavam muito em dar permissão para anatomias públicas por medo de que não se realizassem depois os funerais adequados. ${ }^{73} \mathrm{Os}$ mesmos regulamentos foram estabelecidos mais tarde para a dissecação de cadáveres provenientes de hospitais. ${ }^{74} \mathrm{O}$ corpo devia ser transportado cuidadosamente do hospital para a sala de dissecação e trazido de volta para o funeral. Devia ser o cadáver de um estrangeiro, um não-cidadão da cidade onde se realizava a dissecação, sem parentes morando no local.

Os regulamentos restringiam consideravelmente o potencial de corpos disponíveis. Thijssen calculou que, entre 1693 e 1774, 357 criminosos foram executados em Amsterdã:' nos períodos entre 1631-1645 e 1693-1770, um total de 42 cadáveres foram dissecados em público. Nem Thijssen nem qualquer outro autor mencionam os regulamentos como causa da diferença numérica. ${ }^{75}$ É evidente que a argumentação em defesa desses regulamentos devia ser muito convincente. Uma das razões alegadas que se procurava evitar atrocidades contra parentes e vizinhos do criminoso executado. A vivissecção de cadáveres de criminosos era proibida, porque nesse caso a alma da vítima seria destruída e o ônus recairia sobre o "rei" e o carrasco. Um sepultamento digno era também um direito fundamental, até mesmo para os criminosos de origem humilde. A dissecação pública era encarada como opróbio e, por isso, as autoridades tomavam muito cuidado para que o evento resguardasse ao máximo o anonimato do cadáver.

A autópsia era uma prática usual entre as classes altas da sociedade. A morte de uma pessoa importante era tão relevante que a causa do falecimento (e do erro do médico) devia ser bem determinada. A anatomia pública do corpo de um criminoso não era uma "autópsia", mas às vezes uma dissecação para que se determinasse a causa dos crimes que o tinham levado à pena de morte. $^{76}$

72 E. H. M. Thijssen. Nicolaas Tulp..., op. cit., p. 34.

73 Idem. p. 32.

74 Idem, pp. 28 e 30.

75 Idem. p. 31. 
Uma segunda razão para o anonimato do cadáver era que a pessoa e o crime não tinham maior interesse, de modo que a escolha do corpo para anatomia seguia critérios unicamente científicos: devia ter altura e idade medianas, ser sadio e assim por diante para possibilitar comparações. O que devia ser regulada era a hierarquia dos assentos, a ordem das perguntas e coisas semelhantes, sugerindo que a questão central era a interpretação daquilo que a dissecação revelava. Conforme declarou o poeta holandês Barleus, em 1632, o criminoso que tanto mal fizera à sociedade podia, agora, depois de morto, ser de grande utilidade para ela. ${ }^{77}$ Vida e morte (o corpo morto) já não eram completamente opostos. Assim como Amsterdã fora a primeira cidade no mundo onde as autoridades obrigaram os bandidos a trabalhar a fim de tornar a prisão economicamente produtiva, o criminoso ali executado podia, após sua morte e por meio dela, servir à sociedade. $\mathrm{O}$ poder de exclusão transformara-se em poder de disciplina dos corpos (de criminosos), um poder que agora se estendia para além da morte. ${ }^{78}$

Dúvidas crescentes a respeito da validade científica da anatomia pública fez com que os médicos insistissem na autorização para realizar anatomias na esfera privada ou nas sociedades eruditas informais, e para a provisão de corpos por intermédio dos hospitais. Além disso, no final do século XVII, anatomistas como Frederik Ruysch inventaram técnicas de preservação de cadáveres, ou de partes deles, por tempo ilimitado, o que permitia a realização de dissecações em qualquer época do ano. ${ }^{79}$ As grandes sessões públicas de anatomia eram vistas como inadequadas para a qualidade do ensino e para a pesquisa científica.

\section{Os regulamentos ingleses}

A concepção de Heckscher e Turner, de que a dissecação pública era uma "segunda morte", também se aplica à situação da Inglaterra, exceto pelo fato de que lá não se fazia dissecação em público. A idéia de uma "segunda morte" vem à baila com a chamada Lei do Homicídio (Murder $A c t$ ), de 1752. Até aquela época, o Royal College of Physicians (Colégio dos Médicos) e a Company of Barber-Surgeons (Sociedade dos Cirurgiões-Bar-

76 Beschryving Bleyswijck, Der Stadt Delft. Delft, 1667, pp. 575-6.

77 B. W. Th. Nuyens, Het ontleedkundig onderwis..., op. cit., p. 75.

78 M. Foucault, Surveiller et Punir..., op. cit., pp. 208-11.

79 Ver J. C. C. Rupp. "Matters of Life...”, op. cit., p. 277. 
beiros) detinham a prerrogativa, concedida por Elizabeth e Carlos II, da dissecação anual de criminosos executados. Segundo Peter Linebaugh, a Coroa e o Legislativo estavam menos interessados no progresso da ciência que na antecipação do opróbio para o "rebotalho do povo". ${ }^{80} \mathrm{O}$ preâmbulo da Lei do Homicídio declarava: "Tornou-se necessário que alguma outra forma de Terror e uma Marca de Infâmia peculiar sejam acrescentadas ao Castigo." À morte por enforcamento somava-se a dissecação pelos cirurgiōes, como meio de tornar a sentença mais assustadora. A lei atribuiu aos juízes a faculdade de, no caso de sentenças de morte por homicídio, substituir a exposição a ferros, com o corpo coberto de alcatrão e lançado à rapinagem dos pássaros, pela dissecação. Como castigo exemplar, a exposição a ferros só era superada pela força da dissecação. Declarava-se explicitamente que em nenhuma circunstância se impediria o sepultamento do corpo de um assassino ${ }^{81} \mathrm{O}$ dispositivo contrário ao sepultamento cristão de assassinos encontrava particular destaque e justificativa na letra da Bíblia, que fala em queimar nos infernos, a segunda morte. ${ }^{82}$

Ao contrário da Itália. Holanda e França, as dissecações jamais se tornaram públicas na Inglaterra. Realizavam-se na esfera privada do College of Physicians ou da Company of Surgeons, na presença apenas de cirurgiōes, médicos e estudantes de medicina (Linebaugh fala de dissecações públicas, mas sua tese é infundada). Funcionários do governo ou o público em geral não assistiam às sessões. Tal situação acabou por desencadear uma importante polêmica sobre se, em nome do progresso da ciência, as experiências e outros procedimentos científicos deviam ser testemunhados e discutidos por colegas na esfera privada da comunidade científica ou pelo público em geral em um amplo debate. Robert Boyle representou o primeiro ponto de vista, que veio a predominar, e Thomas Hobbes defendeu a segunda posição. ${ }^{83}$

Embora ilegais, muitas escolas particulares foram fundadas por médicos durante a segunda metade do século XVIII. Nelas, enfatizava-se a ciência empírica e o aprendizado prático, em oposição aos métodos de demonstração e debate do Royal College. ${ }^{84} \mathrm{~A}$ necessidade de cadáveres aumentou repenti-

80 P. Linebaugh, "The Tyburn Riot Against the Surgeons". in D. Hay et alli, orgs., Albion's Fatal Tree. Crime and Sociery in Eighteenth Century England. Londres. 1975, p. 73.

81 R. Richardson, Death. Dissection and the Destitute, Londres, 1987. pp. 36-7.

82 P. Linebaugh. “The Tyburn Riot...”. op. cit.. pp. 77-8.

83 S. Shapin e S. Schaffer, Leviathan and the Air-Pump. Hobbes. Boyle and the Experimental Life. Princeton. Princeton University Press, 1985. pp. 38-40. 55-6. 112-4 e 283-331. 
namente, embora a concessão real de quatro corpos de criminosos por ano fosse suficiente para as demonstrações do Royal College e da Company of Barber-Surgeons. Com isso se desenvolveu um comércio privado de cadáveres, roubados dos patíbulos, cemitérios, hospitais e até mesmo das residências por bandos especializados.

O povo muitas vezes se revoltou contra essas práticas, assim como se insurgira contra as formas cruéis de execução pública. Na Inglaterra, não era de conhecimento popular a regra de que apenas criminosos "estrangeiros" podiam ser dissecados e que todos tinham o direito a um sepultamento digno ${ }^{85}$ A prerrogativa do sepultamento decente era considerada um direito inalienável. Ruth Richardson escreveu:

"A danificação de cadáveres de criminosos executados - esquartejamento de traidores
e uso da dissecação de assassinos - constituiu historicamente uma violação jurídica
deliberada das normas e valores mais amplos da sociedade. Tivesse faltado à Inglaterra
um consenso que atribuísse grande importância aos cuidados após a morte e ao sepulta-
mento integral do cadáver, tais punições não teriam significado cultural algum." 86

Parentes, vizinhos, amigos, colegas e conterrâneos ("confederados e outros desordeiros") inventaram toda espécie de artifícios para resgatar os corpos dos seus entes queridos das mãos dos médicos, a fim de dar-lhes um "enterro decente", "à maneira cristã". ${ }^{87}$ As pessoas se dispunham a atravessar grandes distâncias a pé até Tyburn, em Londres, onde se realizavam as execuções, o que era uma aventura arriscada. Algumas vezes elas conseguiam fazer um trato com o carrasco: na época em que o enforcamento se dava por estrangulamento, o carrasco fazia com que o prisioneiro apenas perdesse a consciência, de modo que a família pudesse alegar uma "ressurreição";8 com o reconhecimento dessa ocorrência, a vítima não podia ser enforcada de novo. Disputas por cadáveres entre cúmplices dos médicos do Royal College e das escolas particulares, e entre estes e os parentes e amigos dos criminosos ocorriam regularmente, produzindo grandes conflitos. Médicos e cirurgiões-barbeiros eram freqüentemente ameaçados de morte nessas ocasiões.

84 V. Robinson, "Anatomical Dissection in the 18th. Century”, Ciba Symposia, vol. 3, n 2, 1941 , pp. 826-45 e 849; P. Linebaugh, “The Tyburn Riot...”, op. cit., p. 73.

85 R. Hughes, The Fatal Shore. A History of the Transformation of Convicts to Australia 17871868, Londres, Pan Books, 1987, pp. 34-5.

86 R. Richardson, Death, Dissection and..., op. cit., pp. 28-9.

87 P. Linebaugh, "The Tyburn Riot...”. op. cit., pp. 74-5 e 79.

88 Idem, p. 103. 
Alguns médicos, como Bernard de Mandeville, formularam a primeira defesa utilitarista da dissecação de criminosos sentenciados, ao afirmar que não tinham a intenção de cometer crueldades ou obscenidades com o corpo humano, mas que "a reverência supersticiosa do povo pelo cadáver, até mesmo de um malfeitor, [era] prejudicial para o público: a dissecação era necessária para o avanço da medicina". 89

Somente depois de 1832, ano da Lei da Anatomia, é que cessaram o tráfico de cadáveres e as revoltas contra as dissecações. Um dos problemas era que, pela legislação inglesa, um cadáver não era propriedade de ninguém. ${ }^{90}$ A Lei da Anatomia definia que, a partir de então, também podiam ser usados cadáveres provenientes dos asilos de pobres, se nenhuma família reclamasse o corpo e fosse providenciado um sepultamento. Discutindo essa lei, Jeremy Bentham propôs compensar a escassez de cadáveres obrigando os pacientes de hospitais a colocar seus corpos à disposição do médico. que se responsabilizaria por assegurar um sepultamento cristão, em respeito aos sentimentos dos parentes. Coerentemente, ele próprio colocou seu corpo à disposição da ciência após sua morte. As palavras que usou naquela ocasião lembram as frases do poeta holandês Barleus, em 1632: "para que, em meus últimos momentos, eu receba o conforto de saber que, apesar do pouco serviço que tenha podido prestar à humanidade durante minha vida. poderei, pelo menos, não ser de todo inútil após a morte". 91

\section{Os regulamentos franceses}

William Hunter, um importante anatomista londrino, chamou de "estilo parisiense" de dissecação, ao tratar do método pelo qual cada estudante dissecava sozinho um cadáver inteiro. ${ }^{92}$ Em muitos aspectos, a tradição francesa diferia da italiana, da holandesa e da inglesa. A pesquisa de Gelfand sugere a existência de uma multiplicidade de normas baixadas por diversas

89 Idem, p. 72.

90 R. Richardson, Death, Dissection and..., op. cit., p. 58.

91 P. Linebaugh, “The Tyburn Riot...”. op. cit., p. 110.

92 T. Gelfand, "The 'Paris Manner' of Dissection: Student Anatomical Dissection in Early Eighteenth Century Paris". Bulletin of the History of Medicine, vol. 46, 1972, pp. 99-103; T. Gelfand, Professionalizing Modern Medicine, Paris Surgeons and Medical Science and Institutions in the 18th. Century. Westport, Greenwood Press, 1980; C. Lawrence, "Alexander Monroe Primus and the Edinburgh Manner of Anatomy", Bulletin of the History of Medicine. vol. 62,1988 , pp. 193-214. 
autoridades. Além da autoridade da Coroa e do Parlamento, havia o poder da Igreja sobre os hospitais, as autoridades acadêmicas e as associações de médicos e cirurgiões-barbeiros. No século XVII, e apenas em Paris, a anatomia podia ser praticada em seis instituições oficiais, além de várias escolas particulares. A Faculdade de Medicina de Paris ocupava-se das aulas de anatomia para cirurgiões-barbeiros e estudantes de medicina desde o início do século XV. Os médicos deixavam a dissecação aos cuidados dos cirurgiões-barbeiros; nas aulas particulares, eles as executavam pessoalmente. Às vezes, os próprios estudantes tinham a oportunidade de realizar dissecações (Andreas Vesalius foi um desses). ${ }^{93}$ Durante os séculos XVI e XVII, o Parlamento concedeu aos professores de medicina o monopólio da distribuição de cadáveres e do ensino da anatomia. ${ }^{94}$ Não encontrei nenhum documento que afirmasse que apenas os cadáveres de "estrangeiros" podiam ser dissecados na França.

Em Paris havia também o Hôtel Dieu. Ali, o famoso cirurgião Ambroise Paré praticou a anatomia no século XVI. Os cursos incluíam anatomia normal e patológica, particularmente no caso de doenças passíveis de cirurgia. O programa incluía experiências fisiológicas. Havia abundância de material anatômico no hospital, embora a política oficial proibisse as dissecações por conflitarem com a caridade e humanidade cristãs. Um regulamento permitia que cirurgiões da instituição realizassem autópsias na presença de médicos do hospital. Em 1706, um outro regulamento determinava que apenas a madre superiora poderia autorizar a retirada de cadáveres da salle des morts, por incumbência do cirurgião-mestre do hospital. Eram definidas épocas especiais para a preparação das peças e a realização de demonstrações no anfiteatro. Os cirurgiōes de fora do hospital somente podiam assistir à anatomia com a permissão da direção. ${ }^{95}$

Pode-se deduzir desses regulamentos que o hospital não se entusiasmava muito com a idéia de abrir mão dos cadáveres para autoridades externas, apesar dos pedidos urgentes e, algumas vezes, dos decretos reais. A direção do hospital citava a indignação pública, o medo e os sentimentos religiosos como razões para sua oposição à anatomia pública. Em 1749, a direção declarou que a distribuição de corpos para a prática da anatomia fora da instituição enfrentava forte resistência por parte do público e causava repulsa

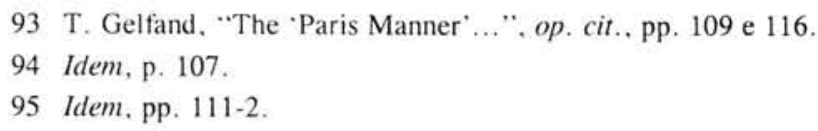


e antipatia contra o hospital. ${ }^{96}$ Uma tentativa de evitar esses problemas consistiu em dar à anatomia a aparência respeitável de uma autópsia.

Em 1668, o cirurgião da Corte tornou-se mestre da guilda de Paris e de todas as demais guildas do país. O rei e os ministros estavam muito interessados na cirurgia por causa da guerra. Isso levou a um grande desenvolvimento da anatomia e da cirurgia. Mediante Decreto Real de 1673, autorizouse .o Jardin du Roy a realizar intervenções cirúrgicas, dissecações e demonstrações de anatomia com total liberdade. Concedeu-se ao Jardin prioridade sobre os professores de medicina para dar destino aos cadáveres retirados do patíbulo da cidade. Essas demonstrações de anatomia eram públicas, atraindo a elite parisiense e uma platéia, em geral, de 400 a 500 pessoas, inclusive muitos estrangeiros. Na opinião de Gelfand, filósofos e escritores demonstravam um interesse particular pela eloqüência do anatomista e pelo espetáculo em si. Os professores de anatomia removiam corpos do patíbulo, do Chatelêt (para onde eram levadas as pessoas assassinadas encontradas nas ruas) e dos hospitais. A direção do hospital hesitava em fornecer cadáveres, porque suspeitava que os anatomistas do Jardin estivessem comprando ilegalmente corpos dos coveiros do cemitério do hospital. ${ }^{97}$ Também o rei estimulava o ensino de anatomia e cirurgia na escola de Saint Côme e no hospital da Charité. Neste último, realizavam-se autópsias em todos os pacientes, e dissecações completas eram executadas durante o inverno para uma platéia de cirurgiões-barbeiros e de médicos. Era expressamente proibido tocar nos cadáveres que já estivessem enterrados. O sepultamento adequado dos restos mortais, após a autópsia ou a dissecação, era obrigatório.

Finalmente, havia cursos nas écoles particulières, onde os próprios estudantes podiam se exercitar em anatomia. Embora apenas as escolas públicas e os hospitais fossem abastecidos de cadáveres, era contraditoriamente mais fácil para os professores particulares comprar corpos, principalmente nos cemitérios. A razão disso era que a dissecação ocorria na esfera particular, a não ser que um acaso ou uma indiscrição causasse um escândalo e obrigasse à intervenção da polícia. ${ }^{98} \mathrm{~A}$ necessidade de bons cirurgiões obrigou o rei e o governo a fazerem "vista grossa" contanto que o tráfico fosse feito com discrição. ${ }^{99}$ Ao longo do século XVIII, os filósofos do Iluminismo fizeram muitas críticas ao que classificavam como superstição

96 Idem, p. 115.

97 Idem, pp. 105-6 e 188.

98. Idem, p. 117.

99 Idem, pp. 128-30. 
com respeito às dissecações. Diderot dizia, por exemplo, que em uma sociedade civilizada, os padres só deveriam receber cadáveres dissecados por anatomistas. A lei deveria proibir todo funeral que não fosse precedido de uma autópsia em prol do avanço da ciência. A direção do Hôpital Général declarou, em 1731, que a repulsa natural dos habitantes pela dissecação era compreensível, mas os pobres tinham de cumprir suas obrigações para com uma sociedade que lhes dera proteção. ${ }^{100}$

\section{Segunda discussão}

No início da seção sobre os regulamentos da anatomia, lancei a hipótese de que esta adotou a forma de dissecações públicas em um anfiteatro porque, dessa maneira, as autoridades podiam controlar a distribuição de cadáveres para dissecação e garantir a obediência às demais normas da anatomia, além de evitar o tráfico ilegal de corpos. O pressuposto parece confirmar-se naqueles países cujo soberano ou governo atribuíam grande importância à anatomia para o bem-estar social. Na França, o rei só conseguiu alcançar a necessária autoridade central na segunda metade do século XVII. A Inglaterra jamais conheceu teatros para anatomia pública. A dissecação do corpo do criminoso era considerada, nesse país, como uma segunda morte, devendo ser executada no interior do círculo privado dos médicos; além disso, o rei e o Parlamento podiam negar ao criminoso o direito a um sepultamento. Os médicos eram a extensão da onipotência do monarca. Na Holanda, a anatomia pública era vista como uma lição moral a respeito da fragilidade da existência humana e como uma advertência quanto às conseqüências de um comportamento criminoso, mas os regulamentos davam grande ênfase ao direito a um sepultamento digno.

Uma segunda razão para a ausência de sessões de anatomia pública na Inglaterra é que, nesse país, os médicos sempre tiveram fortes dúvidas quanto ao valor científico e educativo das dissecações públicas. Admitia-se que o progresso da ciência só poderia ser alcançado pela educação empírica e pelas discussões dentro do círculo privado das sociedades eruditas. Somente filósofos como Thomas Hobbes sustentavam que um debate público era indispensável para o progresso da ciência. Nos outros países, a utilidade da anatomia pública passou a ser gradualmente contestada e na Holanda, por

100 Idem, pp. 129-30. 
exemplo, ela foi privatizada na década de 1670 . Instrumentos indispensáveis, como microscópios, só podiam ser usados na esfera privada.

$\mathrm{Na}$ Itália, França e Holanda, onde as autoridades tinham grande interesse pela anatomia, não houve escassez de cadáveres; na Inglaterra. onde a Coroa revelava menos interesse tanto no progresso científico quanto na punição de criminosos, assim que se afirmou a importância do ensino empírico e foram fundadas as escolas particulares, contrapondo-se às demonstrações organizadas pelo College of Physicians, houve, de fato, escassez de corpos.

Por ocasião dos preparativos para as sessões de anatomia pública, um dos problemas era conciliar os diferentes interesses em conflito. Além do interesse geral no progresso da ciência médica (em proveito da cirurgia, da obstetrícia e do avanço geral da medicina), havia a reivindicação do direito a um sepultamento digno. As reações populares em cada um dos países estudados levam a crer que este era um direito básico e inalienável da pessoa humana e de seu meio social. Na República Unida dos Países Baixos, os médicos parecem ter se adaptado melhor a essa lei. Além disso, nesse país, bem como na Itália, só se permitia a dissecação de corpos de não-cidadãos, a fim de evitar a desonra de parentes e amigos. Ao contrário da França e da Inglaterra, onde os "cidadãos" eram súditos da Coroa, os "cidadãos" na Holanda e na Itália eram pessoas nascidas, ou habitantes permanentes, em uma cidade que constituía uma unidade política relativamente autônoma.

Esses problemas se tornaram mais delicados quando as autoridades passaram a fornecer para dissecação cadáveres provenientes dos hospitais. Isso colocou problemas para a pesquisa científica realizada na esfera médica privada. Na Holanda, Itália e França os médicos também tiveram de aceitar o direito de todos a um sepultamento cristão e tiveram de agir do modo mais cuidadoso e discreto possível na transferência dos cadáveres. Na Inglaterra, só depois de 1832 os médicos foram obrigados a garantir um sepultamento adequado após a dissecação. Antes dessa data, negava-se ao criminoso o direito ao sepultamento, e seus parentes e amigos insurgiam-se freqüentemente para resgatar o corpo das mãos dos médicos.

Um terceiro tipo de interesse geral era o dos pacientes e o da reputação dos hospitais. Prover corpos a partir dos hospitais significava dispor dos cadáveres dos pobres. As direções religiosas dos hospitais, principalmente na França, eram muito ciosas da boa reputação de suas instituições. Elas faziam questão de que os médicos dessem à anatomia a categoria de uma autópsia. Essa forma de anatomia era, há muito, conhecida das famílias mais proeminentes, que lançavam mão da mesma quando ocorria um problema 
legal ou médico. Quanto ao conflito moral implícito na utilização de cadáveres de criminosos e de pobres em benefício da ciência, os holandeses já tinham formulado, em 1632, uma justificativa que considerava a utilidade do criminoso para a sociedade após sua morte. Fazia parte do discurso dos filósofos iluministas franceses a idéia de que os pobres, que tanto haviam recebido da sociedade, Ihe deviam gratidão. Jeremy Bentham tinha plena consciência disso quando, em 1832, voluntariamente colocou seu corpo à disposição da ciência da medicina.

Durante as dissecações públicas, todos os tipos de regulamentos eram aplicados. A platéia mista, composta de grupos portadores dos mais diversos interesses no evento, criava cenas caóticas. As regras ditavam que todos deviam se comportar com tranqüilidade, que os grupos permaneceriam nos lugares que lhes tinham sido reservados, que não era permitido obstruir a visão dos outros e que as discussões se processariam de modo ordeiro e amistoso. Esses regulamentos também se aplicavam às sociedades eruditas e. no século XIX, também aos teatros, casas de concerto e outros centros culturais. Segundo Norbert Elias, ${ }^{101}$ esse processo pode ser chamado de formalização das relações humanas.

\section{Conclusões}

A análise das práticas e regulamentos da anatomia na Itália, Holanda, França e Inglaterra pré-modernas sugere que a tese de Foucault só se confirma em parte. Até a segunda metade do século XVII, o "discurso clínico" era certamente predominante. Os médicos sentiam-se frustrados pelo veredicto da Igreja a respeito da vivissecção de seres humanos e do cérebro de animais e preferiam experiências fisiológicas com animais vivos, como as de Boyle com oxigênio comprimido. No entanto, depois de 1670 , cresceu a importância do "discurso anatômico".

Teria havido, de fato, uma escassez de cadáveres? A resposta depende não só dos discursos médicos em conflito, mas da divergência de opiniões acerca do ensino, das condições necessárias ao progresso da ciência e, acima de tudo, do interesse do governo na anatomia. Além disso, a moralidade exercia uma significativa influência, especialmente na definição do direito a um sepultamento digno dos restos mortais. Apesar dos esforços dos cientistas

101 N. Elias, Civilizing Process: The History of Manners, Oxford, Blackwell, 1978; N. Elias, O Processo Civilizatório. Rio de Janeiro, Jorge Zahar Editor. 1990 e 1993. 
e filósofos para aviltar esse direito "como superstição das massas", ele foi finalmente reconhecido em todos os países. A moralidade não foi necessariamente um obstáculo ao progresso da ciência, mas uma decorrência de uma política do corpo.

\section{RESUMO}

\section{Michel Foucault, a Política do Corpo e a Expansão} da Anatomia Moderna

A Nova Ciência e as artes experimentaram um grande desenvolvimento na Holanda do século XVII. Os anfiteatros de anatomia de Leiden, Delft e Amsterdã tiveram uma relevância especial nesse desenvolvimento. Esses anfiteatros foram importantes centros culturais de artes e ciências, pontos de encontro de artistas e cientistas e locais abertos a eventos públicos. Qual o papel da anatomia no surgimento e expansão da ciência moderna? Muitos estudiosos acreditam que a religião, melhor dizendo, a moralidade, fazia forte objeção à anatomia, mas, se assim for, fica difícil explicar por que os anfiteatros de anatomia alcançaram tamanha significação. A tese de Michel Foucault é a de que não houve impedimento por parte da religião e da moral, e sim um antagonismo entre dois discursos médicos, o da clínica (do lado da vida) e o da anatomia (do lado da morte). Este artigo examina a tese de Foucault, investigando as práticas e regulamentos da anatomia na Itália, Holanda, Inglaterra e França pré-modernas. As conclusões sugerem que, além do antagonismo dos discursos médicos, também tiveram importância as opiniões conflitantes a respeito do ensino, das condições do progresso científico e, principalmente, o interesse do governo na anatomia. A questão de se os padrões morais foram um obstáculo ao progresso da ciência relacionava-se essencialmente a uma política do corpo.

\section{ABSTRACT \\ Michel Foucault, Body Politics and the Rise and Expansion of Modern Anatomy}

The New Science and the arts flourished vigorously in the seventeenth century Netherlands. Of special importance were the anatomical theatres in Leiden. Delft and Amsterdam. These theatres were important cultural centres in the sense that they centres of arts ans sciences, meeting places for 
artists and scientists, and places with a public function. What role did anatomy played in the rise and expansion of modern science. Many scholars assume that religion, and more generally speaking, morality, was strongly opposed to anatomy, but then it is difficult to explain how anatomy and anatomical theatres could be of such central significance. It is Michel Foucault's thesis, however, that there was no hindrance by religion and morality, but an antagonism between two medical discourses, the clinical (life) and the anatomical (death). This thesis is tested by exploring anatomy practices and regulations in early modern Italy, Holland, England and France. The results indicate that, not only antagonism between medical discourses, but also conflicting opinions on teaching and the conditions for scientific progress, and, most of all, the interest taken by government in anatomy, played a part. The question as to whether moral standards were a hindrance to the advance of science, was primarily dependent on body politics.

\section{RESUME}

\section{Michel Foucault, la Politique du Corps et l'Expansion de l'Anatomie Moderne}

La nouvelle science et les arts ont connu un grand développement en Hollande au XVIIème siècle. Les amphithéâtres d'anatomie de Leiden, de Delft et d'Amsterdam ont joué un rôle tout spécial dans ce développement. Ces amphithéâtres constituèrent alors d'importants centres culturels consacrés aux arts et aux sciences, des carrefours où se rencontraient les artistes et les scientifiques, des lieux ouverts aux événements publics. Quel fut le rôle de l'anatomie dans l'apparition et l'expansion de la science moderne? Beaucoup de spécialistes affirment que la religion, ou plutôt la moralité opposait de fortes objections à l'anatomie. Mais alors il est difficile d'expliquer pourquoi les amphithéâtres atteignirent une telle signification. Selon Michel Foucault, l'obstacle ne provenait pas de la religion ou la morale mais bien plutôt de l'antagonisme qui opposait alors deux discours médicaux: celui de la clinique (du côté de la vie) et celui de l'anatomie (du côté de la mort). Cet article analyse la thèse de Foucault à partir de l'examen des règlements qui s'appliquaient à l'anatomie aussi bien en Italie qu'en Hollande, en Angleterre et en France à l'époque pré-moderne. Les conclusions conduisent à penser que des facteurs autres que l'antagonisme des discours médicaux ont joué un rôle important: le conflit des opinions concernant l'enseignement ou les conditions nécessaires au progrès scientifique et, prin- 
cipalement, l'intérêt du gouvernement pour l'anatomie. Si les valeurs morales ont constitué un obstacle au progrès de la science, il s'agit là d'une question ayant trait essentiellement à la politique du corps. 